\title{
Chapter 21 \\ Diaspora Policies, Consular Services and Social Protection for Swiss Citizens Abroad
}

\author{
Lorenzo Piccoli
}

\subsection{Diaspora Policy Infrastructure and Key Policies}

This chapter presents the policies of Swiss institutions in their dealings with Swiss abroad, with a specific focus on the area of social protection. The chapter is divided into two main sections. First, it describes the general institutional framework by which Swiss institutions interact with nationals abroad, as well as the main engagement policies with this population. The second part of the chapter focuses on the policies, programmes and services offered by Swiss institutions to respond to the social protection needs of Swiss abroad across five specific policy areas: unemployment, health care, pensions, family benefits, and guaranteed minimum resources. This chapter explains how the Federal Council has gained control over this network of institutions starting from the 1960s. The centralization of social protection towards Swiss abroad was the result of a new legislation recognizing the crucial role of Swiss nationals abroad in shaping both internal politics and the external image of Switzerland. As part of this strategy, the Federal Council developed more encompassing social protection policies, while safeguarding pre-existent cantonal and charitable associations. As a result, Swiss nationals abroad can access a wide set of social entitlements.

Due to the lack of scientific literature on this topic, the data used for this chapter amount to 19 formal policy-making documents (existing legislation, expired

\footnotetext{
L. Piccoli $(\bowtie)$

University of Neuchâtel, Neuchâtel, Switzerland

Centre for Advanced Studies at the European University Institute,

San Domenico di Fiesole, Italy

e-mail: lorenzo.piccoli@unine.ch
} 
legislation, motions to the Federal Assembly, official guidelines and regulations), as well as a set of six interviews with policy-makers and experts. ${ }^{1}$

\subsubsection{Diaspora Infrastructure}

The Federal Statistical Office (FSO) estimates that there were 751,800 Swiss nationals living abroad at the end of $2017 . .^{2}$ Of these, $73.5 \%$ had dual citizenship, $62 \%$ were based in Europe and $54.4 \%$ were women. ${ }^{3}$ In terms of countries of destination, France has the largest Swiss expatriate community in Europe (193,300 in 2017), followed by Germany $(88,600)$ and Italy $(49,600)$. Outside Europe, the majority of Swiss citizens live in the United States $(79,900)$, Canada $(39,700)$, Australia $(24,900)$ and Israel $(19,900)$. In total, Swiss nationals abroad represent $11 \%$ of the total Swiss population. They are often referred to as the "Swiss colony", the "community of Swiss abroad", or the "fifth Switzerland" (Fünfte Schweiz), alluding to the fourfold linguistic division within Switzerland.

There is virtually no academic research on the policies towards the Swiss abroad. This stands in stark contrast with the relative abundance of studies targeting specific communities of Swiss abroad. Scholars have researched the Swiss in the Americas (Arlettaz 1979), Argentina (Glatz 1997), Australia (Wegmann 1989), Brazil (Dewulf 2007), Canada (Bovay 1976), Chile (Schneiter 1983), China and North European countries (Camenisch and Muller 2017), Poland (Andrzejewski 2002), Russia (Bühler et al. 1985) or Romania (Chinezu 2002). Some scholars have even studied cantonal emigrants, like the Ticinese in California (Perret 1950) and the Bernese in the United States (Geissbuhler 1999). Yet, no systematic study has been conducted on the institutional structuring of the relationship between the Confederation and the Swiss nationals abroad.

\footnotetext{
${ }^{1}$ The full list of interviews includes: 1) Director at the Organisation of the Swiss Abroad (14/6/2018, Bern); 2) Division Director at the Federal Council: Eidgenössisches Departement für auswärtige Angelegenheiten Konsularische Direktion, Zentrum für Bürgerservice Sozialhilfe für Auslandschweizer/innen (5/9/2018, Bern); 3) Division Director at the Federal Council: Eidgenössisches Departement für auswärtige Angelegenheiten, Konsularische Direktion, Delegierte für Auslandschweizerbeziehungen (14/9/2018, Bern); 4) Division Director at the Federal Council: Dienst Sprachen und Gesellschaft, Bundesamt für Kultur (26/9/2018, Bern); 5) Division Director at the Federal Council: Département fédéral de l'intérieur, Office fédéral des assurances sociales, Affaires internationales (3/10/2018, Bern); 6) Former Director at the Organisation of the Swiss Abroad (4/10/2018); Director of the Associazione Gazzetta Svizzera (5/10/2018, Milan).

${ }^{2}$ Federal Statistical Office of Switzerland (2018). Statistics on the Swiss Abroad. https://www.eda. admin.ch/eda/en/home/living-abroad/publications-statistics/statistics.html. Accessed 18 March 2019.

${ }^{3}$ Most dual nationals lived in Oceania (78.3\%), North and South America (77.2\%), and Europe (73.7\%). In Africa and Asia, the percentage of dual nationals was around $60 \%$.
} 
Historically, the Federal Council has actively worked towards guaranteeing the social protection of Swiss abroad. Since 1846, the main institution that is responsible for engaging with Swiss nationals abroad is the Federal Department of Foreign Affairs (FDFA, Eidgenössisches Departement für auswärtige Angelegenheiten). In addition to protecting Switzerland's interests abroad, the FDFA has among its main tasks the improvement of services for Swiss nationals living abroad and the maintenance of the administrative register of the Swiss abroad E-VERA, which contains information on the Swiss nationals abroad. ${ }^{4}$

Within the FDFA, the Consular Directorate (CD, Konsularische Direktion) oversees the mobility of Swiss nationals abroad. In particular, the CD's Delegate for Relations with the Swiss Abroad promotes the interests of Swiss nationals abroad and coordinates the working of the 170 embassies and consulates around the world, as well as 200 honorary consulates. Honorary consulates have, among their main tasks, the conduct of official relations with the authorities in the host country and information sharing. They can also provide advice to Swiss abroad and, in agreement with the embassy or consulate or with the FDFA, they can take the appropriate measures for Swiss abroad who are in a situation of physical or financial risk and demand assistance.

The Federal Council actively supports institutions that promote relations and assist Swiss abroad. Among these, the Organisation of the Swiss Abroad (OSA, Die Auslandschweizer-Organisation) plays a particularly prominent role. This nonprofit organisation was established during World War I, in 1916, under the umbrella of the New Helvetic Society (NHS, Neue Helvetische Gesellschaft), which had itself been created 2 years earlier to defend the unity of the young Helvetic Confederation. The OSA was initially operative abroad. It set up a permanent secretariat in Geneva in 1919, which was then moved to Fribourg in 1923, and then in Bern in 1928. In 1924, the OSA started to receive financial support from the Federal Council. Today, its activities are enshrined in Article 9.2 and Article 38 of the Federal Act on Swiss Citizens and Institutions Abroad. ${ }^{5}$ It has three main tasks: providing services for Swiss nationals abroad, communicating with them, and representing them in Switzerland. More specifically, the OSA provides advice on all types of legal, social security insurance and training matters; it publishes the bimonthly magazine "Swiss Review" and promotes active cultural and educational programmes for young Swiss nationals abroad. The OSA also organizes the Congress for Swiss nationals abroad, which takes place every year in a different city

\footnotetext{
${ }^{4}$ The register is updated through the notifications sent to the FDFA by the municipal offices upon departure and return of Swiss nationals. According to information estimations of the government officials, in addition to the 751,800 persons who were officially registered to live abroad in 2017 , there are about 250.000 Swiss abroad who has not registered in E-VERA.

${ }^{5}$ The two articles read, respectively: "The Confederation shall maintain contact with institutions that promote relations between the Swiss Abroad and that contribute to better support and networking of the Swiss Abroad, particularly the Organisation for the Swiss Abroad" and "[The Confederation] may grant financial support to the Organisation for the Swiss Abroad to safeguard the interests of the Swiss Abroad and to provide them with information".
} 
Table 21.1 Annual subsidies of the Swiss Federal Council to the Organisation of the Swiss Abroad, in Swiss francs (1980-2015)

\begin{tabular}{l|l}
\hline Year & Amount \\
\hline 1980 & 1.260 .885 \\
\hline 1985 & 1.154 .200 \\
\hline 1990 & 717.413 \\
\hline 1995 & 1.235 .782 \\
\hline 2000 & 1.171 .911 \\
\hline 2005 & 3.178 .442 \\
\hline 2006 & 3.225 .000 \\
\hline 2007 & 4.001 .355 \\
\hline 2008 & 3.270 .430 \\
\hline 2009 & 2.800 .000 \\
\hline 2010 & 2.663 .520 \\
\hline 2011 & 2.723 .384 \\
\hline 2012 & 3.037 .073 \\
\hline 2013 & 3.253 .360 \\
\hline 2014 & 3.263 .513 \\
\hline 2015 & 3.075 .133 \\
\hline 2016 & 3.212 .374 \\
\hline 2017 & 3.056 .261 \\
\hline
\end{tabular}

Source: Own elaboration based on data from the FDFA

of Switzerland. The directors of the OSA hold at least four official meetings with representatives of the $\mathrm{CD}$ every year and the OSA receives three million francs (approximately two million and sixty-five hundred euro) per year from the Swiss Federal Council to carry out its activities (Table 21.1). ${ }^{6}$

The Foundation for Young Swiss Abroad (FYSA, Stiftung für junge Auslandschweizer) is also directly connected to the Swiss Federal Council and its role is enshrined in Article 9.3 of the Federal Act on Swiss Citizens and Institutions Abroad. ${ }^{7}$ This Foundation was created under the name Swiss Aid in 1917, in order to allow Swiss children living in disaster-torn areas abroad to spend a couple of weeks relaxing with host families in a quiet setting. The first holiday camps were organised in the 1960s, while the Foundation took its current name in 1979.

Similar to the working of the FYSA, educationsuisse also promotes the training of young Swiss abroad and works closely with Swiss schools abroad and with international schools where Swiss teachers teach. This non-profit organisation was established in 1942 as "Help Committee for Swiss Schools Abroad" and was later on simply renamed as "Committee for Swiss Schools Abroad". Since 2012, it is

\footnotetext{
${ }^{6}$ Banque de données des subventions fédérales, 2018

${ }^{7}$ Loi fédérale sur les personnes et les institutions suisses à l'étranger, 26/9/2014: "[The Confederation] shall promote exchange between young Swiss Abroad and encourage their ties to Switzerland."
} 
known as educationsuisse and, following the Federal Act on the Diffusion of Swiss Education Abroad, it is economically supported by the Federal Council, Office of Culture (OC, Bundesamt für Kultur). ${ }^{8}$

All Swiss abroad registered with a Swiss representation, except those living in Italy, receive the bi-monthly magazine Swiss Review (Schweizer Revue), which reports specifically on issues which interest Swiss abroad and strengthens their ties with the home country. Special emphasis is given to politics, so that Swiss citizens living abroad can exercise their electoral rights in a responsible and informed manner. Because it contains governmental information and announcements, the Swiss Review also serves as an official publication organ. Since 1973, the Review has been published by the OSA in Bern, which receives public funding from the FDFA for the publication. Edited to 422,000 copies, it is politically neutral.

Swiss nationals living in Italy do not receive the Swiss Review. Instead, they can sign up for the Swiss Gazette (Gazzetta Svizzera), which was created by the then cultural attaché of the Swiss embassy in Milan in 1968. This magazine, published in Italian, aims at strengthening the links between the various Swiss colonies in Italy and maintaining the bonds with Switzerland. It is managed by the Swiss Gazette Association (Associazione Gazzetta Svizzera), which was established in 1995. The Association is subsidised for one third by the Swiss Federal Council and for two thirds by the readers. Its annual budget of around 300,000 francs is used to publish 11 issues per year. The Swiss Gazette is read by about 30,000 people, with 22,000 printed copies and about 7000 access online per month. Like the Swiss Review, the Swiss Gazette is politically neutral.

Political parties have traditionally engaged with Swiss nationals abroad. All the main parties that are currently part of the Federal Council (The Liberals; the Social Democratic Party; the Swiss People's Party; the Christian Democratic People's Party) have a branch that maintains the ties with nationals abroad. In 2004, under impulse of the OSA, several members of the Federal Assembly established the Parliamentary Group of the Swiss Abroad, which is coordinated by three Co-Presidents and currently consists of 75 members of both chambers. Its activity is dedicated to the representation of the interests of Swiss nationals abroad and every 3-4 months, the Group releases a newsletter with information on the most important reforms that may affect Swiss nationals abroad. In the current legislature (2019-2023), the Inter-Party Parliamentary Group of the Swiss Abroad is the biggest group in the Federal Assembly.

\footnotetext{
${ }^{8}$ Loi fédérale sur la diffusion de la formation suisse à l'étranger, 21/3/2014.
} 


\subsubsection{Key Engagement Policies}

In public discourses, Swiss nationals abroad are seen as important actors in shaping Switzerland's image in the world. For this reason, the institutions have traditionally invested in fostering cultural networks and have actively promoted the establishment of minimum social standards of protection for Swiss nationals abroad (Arlettaz 1986). The protection of Swiss abroad is enshrined in Article 40 of the Federal Constitution, stipulating that "the Confederation shall encourage relations among the Swiss abroad and their relations with Switzerland. It may support organisations that pursue this objective. It shall legislate on the rights and obligations of the Swiss abroad, in particular in relation to the exercise of political rights in the Confederation, the fulfilment of the obligation to perform military or alternative service, welfare support and social security". This legislation was first introduced as Article 45 of the Constitution in 1966, following a popular initiative with $68 \%$ of approval by the voters. It became Article 40 following the revision of the Constitution in 1999. ${ }^{9}$

More detailed policies in this field are regulated by the Swiss Abroad Act, the Federal Act of 26 September 2014 on Swiss Nationals and Institutions Abroad. ${ }^{10}$ The law includes measures aimed at supporting, informing and promoting links between Swiss nationals abroad, their political rights, social assistance that may be granted to them and support for specific institutions. The Act defines Swiss nationals abroad as those Swiss citizens who "are not domiciled in Switzerland and who are listed in the Register of the Swiss Abroad" and aims at "facilitate[ing] international mobility for Swiss nationals" and "promot[ing] Switzerland's presence and links abroad". Swiss abroad are recognised as being of a unique importance to their homeland regarding knowledge, experience, access and connection.

Swiss abroad are directly involved in political affairs. Since 1992, all Swiss nationals abroad are eligible to vote and to stand as candidates in elections for the National Council and in national referendums, under condition that they register upon moving out of the country. ${ }^{11}$ Moreover, the law entitles Swiss nationals abroad to sign federal initiatives and requests for referendums at the federal level. Twelve cantons also provide the right of vote in cantonal matters and the right to be elected to the respective Council of State to Swiss nationals abroad (Arrighi and Piccoli 2018). ${ }^{12}$

Until 2018, the Federal Council had concluded international social security agreements with 44 countries. The objectives of these agreements are to ensure the equal treatment of citizens from the contracting States, determining the applicable legislation and the payment of social security benefits abroad. Switzerland is also

\footnotetext{
${ }^{9}$ Constitution fédérale de la Confédération suisse, 18/4/1999.

${ }^{10}$ Loi fédérale sur les personnes et les institutions suisses à l'étranger, 26/9/2014. See also: Ordonnance sur les personnes et les institutions suisses à l'étranger, 15/10/2018.

${ }^{11}$ Ordonnance sur les droits politiques des Suisses de l'étranger, 16/10/1991.

${ }^{12}$ The full list of cantons that provide the right to vote in cantonal elections is as follows: BaselLand, Basel-Stadt, Bern, Fribourg, Geneva, Graubünden, Jura, Neuchâtel, Schwyz, Solothurn, Ticino, Zürich.
} 
part of several standard-setting conventions. In accordance with the Agreement on the Free Movement of Persons between Switzerland and the European Union (EU), ${ }^{13}$ relations with EU Member States are governed by the provisions of Regulations (EC) No. 883/04 ${ }^{14}$ and (EC) No. 987/09. ${ }^{15}$ Both regulations coordinate the various European social security systems and apply also for European Free Trade Association (EFTA) countries. ${ }^{16}$

\subsection{Diaspora Policies and Social Protection in Switzerland}

Until recently, the social protection of Swiss abroad was left to ad hoc initiatives by the Federal Council, such as the aid operation to support Swiss abroad following World War II in 1957, as well as to charitable organisations, non-profit organisations, cantonal and municipal institutions. The Federal Council counted 57 organisations providing social support to Swiss abroad in the early 1970s. It also estimated the federal expenditure for Swiss abroad at around 85,000 francs per year, vis-à-vis a cantonal expenditure of about 63,900 francs per year. At the time, it was not unusual that a Swiss expatriate originally from Zürich, for example, obtained social support from his canton while his neighbour from Grisons did not. The uneven social protection accorded to Swiss abroad, as well as the need to coordinate the interventions and the new Article 45 on the rights and obligations of the Swiss abroad introduced in 1966, inspired the Federal Assembly to approve the Federal Act of 21 March 1973 on Social Assistance and Loans to Swiss Citizens Abroad. ${ }^{17}$ It was the first time the federal institutions took the matter of welfare assistance for Swiss nationals abroad in their own hands.

Today, Article 22 of the Federal Act on Swiss Citizens and Institutions Abroad stipulates that "the Confederation grants social assistance to the Swiss Abroad who are in need". Swiss nationals abroad who find themselves in need of social

\footnotetext{
${ }^{13}$ Accord entre la Confédération suisse, d'une part, et la Communauté européenne et ses Etats membres, d'autre part, sur la libre circulation des personnes, 21/6/1999.

${ }^{14}$ Regulation (EC) No 883/2004 of the European Parliament and of the Council on the coordination of social security systems, 29/4/2014.

${ }^{15}$ Regulation (EC) No 987/2009 of the European Parliament and of the Council laying down the procedure for implementing Regulation (EC) No 883/2004 on the coordination of social security systems, 16(9/2009.

${ }^{16}$ Ordonnance sur l"introduction progressive de la libre circulation des personnes entre, d"une part, la Confédération suisse et, d"autre part, l"Union européenne et ses Etats membres, ainsi qu"entre les Etats membres de l"Association européenne de libre-échange, 22/5/2002.

${ }^{17}$ Loi fédérale sur l'assistance des Suisses de l'étranger, 21/3/1973. See also earlier debates in the Federal Assembly: Message du Conseil fédéral à l"Assemblée fédérale concernant l"insertion dans la constitution d"un article 45 bis sur les Suisses à l"étranger, 2/7/1965; and Message du Conseil fédéral à l"Assemblée fédérale concernant un projet de loi fédérale sur l"assistance des Suisses de l"étranger, 6/9/1972.
} 
Table 21.2 Number of Swiss abroad who benefit of social assistance through the Swiss Federal Council (2011-2017)

\begin{tabular}{l|l|l|l}
\hline Year & Assistance abroad & Repatriation & Emergency aid for tourists \\
\hline 2011 & 323 & 142 & 90 \\
\hline 2012 & 307 & 158 & 101 \\
\hline 2013 & 285 & 143 & 114 \\
\hline 2014 & 295 & 144 & 98 \\
\hline 2015 & 262 & 110 & 158 \\
\hline 2016 & 258 & 118 & 148 \\
\hline 2017 & 224 & 88 & 132 \\
\hline
\end{tabular}

Source: Own elaboration based on data from the FDFA

Table 21.3 Financial cost of the social assistance through the Swiss Federal Council, in Swiss francs (2011-2017)

\begin{tabular}{l|l|l}
\hline Year & Payments towards foreign countries & Returns \\
\hline 2011 & 1.761 .608 & 459.042 \\
\hline 2012 & 1.602 .524 & 444.710 \\
\hline 2013 & 1.256 .476 & 767.345 \\
\hline 2014 & 1.579 .510 & 499.817 \\
\hline 2015 & 1.178 .677 & 226.424 \\
\hline 2016 & 1.132 .725 & 234.297 \\
\hline 2017 & 1.113 .319 & 231.154 \\
\hline
\end{tabular}

Source: Own elaboration based on data from the FDFA

protection of any kind, be it matters of health, pension, unemployment, or minimum resources, can contact the Swiss representation responsible for their place of residence abroad. This is part of an official policy called Social security for Swiss citizens abroad (Sozialhilfe für Auslandschweizerinnen und Auslandschweizer) (Table 21.2).

Consulates and embassies normally try to find ways to include the person in the social welfare of the host country, except for emergency cases like hospitalisation, when the representation grants the essential emergency aid and notifies the Consular Directorate (CD). ${ }^{18}$ Most often, however, the person fills an application which is first reviewed and completed by the representation responsible for her/his place of residence abroad and transfers it together with a report and request to the $\mathrm{CD}$ at the FDFA in Bern. The CD decides whether to accept applications following a set of guidelines internal to the ministry. In urgent cases, the representation grants the essential emergency aid and notifies the $\mathrm{CD}$. The $\mathrm{CD}$ may authorise representations to grant additional social assistance on their own initiative. In addition to una tantum financial help, this policy also allows for continuous funding over the years, provided that the individual stipulates a plan together with the CD. Every year, the CD submits to Parliament a budget, part of the broader budget for the FDFA. The

\footnotetext{
${ }^{18}$ Note that the majority of these cases actually concern Swiss temporarily abroad, e.g. tourists.
} 
amount of money spent by the CD has been steadily decreasing over the last 5 years, from 1,7 million francs in 2010 to 1,1 million at the end of 2017 (Table 21.3).

Interestingly, according to Article 25 of the Federal Act on Swiss Citizens and Institutions Abroad, Swiss nationals might be ineligible for social assistance if they have another nationality that is considered preponderant. The internal guidelines of the ministry explain how to determine which of the nationalities is preponderant, namely: (i) the circumstances which led to the applicant's acquisition of the foreign nationality; (ii) the state where the applicant resided during childhood and training; (iii) the length of stay in the current State of residence; (iv) the applicant's relations with Switzerland. ${ }^{19}$ There are some specific situations when, even though the foreign nationality of the applicant is preponderant, social assistance can still be granted on an exceptional basis. ${ }^{20}$ It may be that over time the predominant nationality changes. If social assistance has begun to be granted when Swiss nationality predominates, assistance benefits granted on a regular basis may be maintained even if, over time, the foreign nationality has become preponderant. If a person receiving social assistance acquires a foreign nationality, the payment of assistance benefits should be re-examined.

The persons in need may be advised to return to Switzerland if it is in their or their family's interests to do so. In such cases, the Federal Council shall not or shall no longer pay social assistance benefits abroad. In the event of a return to Switzerland, the Federal Council anticipates the expenses to cover the cost of the travel. It may also anticipate the expenses if the person in need decides to return to Switzerland of her/his own accord. The FDFA runs a counselling service on returning to Switzerland, providing information on entry and living conditions to Swiss nationals returning to Switzerland from abroad.

Article 35 of the Federal Act on Swiss Persons and Institutions Abroad establishes that social assistance recipients must repay the social assistance benefits if they no longer require them and are able to support themselves and their families. ${ }^{21}$ Social assistance benefits may be claimed back up to 10 years after the last payment, unless the receivable was stipulated contractually or by the CD. However, not all the recipients of social assistance are able to pay back the money they have received.

If Swiss nationals die abroad, the foreign authority will inform the local Swiss representation in the country concerned. If this is not done, family members may give the foreign death certificate to a Swiss representation, which will send the document to the deceased's municipality of origin. If a person wishes to be buried in Switzerland, the Swiss representation will also prepare the necessary documents

\footnotetext{
${ }^{19}$ Checkliste mehrfache Staatsbürgerschaft: Welches Bürgerrecht dominiert? Gesetzliche Grundlagen, 1/1/2015.

${ }^{20}$ These situations are the following: (i) minor children, where the predominant nationality of one of the parents is Swiss; (ii) severely disabled persons, where the predominant nationality of one of the parents is Swiss; (iii) persons at risk of imminent death, very serious illness, reversible disability; (iv) in the event of war, natural disaster or political disturbance. In borderline situations, the doubt must benefit the applicant.
}

${ }^{21}$ Loi fédérale sur les personnes et les institutions suisses à l'étranger, 26/9/2014. 
for repatriation. The Federal Council may cover the costs of funerals for Swiss nationals who die abroad and who are without means, provided neither their relatives nor the receiving state is willing to pay the costs.

In addition to these policies, the Federal Council supports institutions that promote relations between Swiss nationals abroad and their ties to Switzerland. Today, more than 750 Swiss associations and institutions overseas are affiliated to the OSA, including humanitarian groups, traditional Swiss clubs, sporting associations, choirs, charities, and family associations. These diverse associations constitute "micro-communities of solidarity, where Swiss identity can be easily transmitted" (Leu 2016: 31). In Paris for example, the Swiss Society of Charity has been operating since 1820 and currently has around 20 volunteers who go to the aid of Swiss nationals who are sick or lonely, help them with administrative matters and make hospital visits. Some of these associations are representative of specific cantons. In Argentina and Brazil, for instance, the association Valaisans du Monde is well established; in Brazil, the association Nova Friburgo represents Swiss nationals from the canton of Fribourg. These associations work closely to Swiss diplomatic missions: although they do not formally participate in the decision-making process, in some countries, they provide information that can help the missions deciding on whether requests for welfare assistance are legitimate. In a few countries, Swiss diplomatic missions rely on these associations to provide first hands-on support to Swiss nationals. While providing social help, these associations also ensure an enduring cultural connection between Swiss nationals abroad and the country of origin. The OAS, for example, supports elderly Swiss citizens with poor economic possibilities who wish to return to their homeland for a visit. Requests must be submitted to the Swiss embassy or consulate where the person resides. The financial support however excludes coverage of unpaid stay taxes (e.g. for overstayers) or other debts incurred in the host country which make it impossible to leave.

The following pages describe in detail the services and policies for five key social protection areas. They focus mostly on EU cooperation agreements because most Swiss nationals abroad reside in these countries.

\subsubsection{Unemployment}

Swiss nationals in the EU benefit from the bilateral Agreement on the Free Movement of Persons signed on 21 June 1999, while Swiss nationals in Iceland, Liechtenstein and Norway benefit from the EFTA Convention signed in Stockholm on 4 January 1960. In principle, anyone who is gainfully employed abroad or is a family member of an individual employed abroad is not insured under the compulsory Swiss OASI/DI scheme. However, they may take out such insurance under certain conditions. Individuals who are gainfully employed in an EU/EFTA Member State by a Swiss employer and are paid by this employer can continue to be covered by the OASI/DI/APG schemes and the unemployment insurance scheme if their salary is paid in Switzerland, by the Swiss employer; or, alternatively, if the employer 
agrees that the employee continues to be insured in Switzerland. Insurance cover, however, can only be continued if the individual concerned has been insured for five consecutive years in the compulsory or optional OASI/DI scheme, either directly prior to taking up employment abroad or - for individuals who have been posted in an EU/EFTA Member State while still insured in Switzerland - directly after the termination of their employment abroad. For continued insurance during employment in an EU country, Swiss nationals and citizens of EU Member States can use insurance periods in EU or EFTA countries to count towards this five-year period. The same applies for EFTA nationals for continued insurance during employment in Iceland, Liechtenstein or Norway. Continued insurance cover in Switzerland does not exempt a person from any social insurance obligations in his/her country of employment. Swiss consulates and embassies can assist Swiss abroad in their dealings with unemployment benefits, by helping them to navigate the legislation.

For Swiss nationals who move abroad, unemployment benefits can be paid abroad under certain circumstances and for a maximum of 3 months. After registering with the Swiss employment services, insured persons must remain available to the competent employment service for 4 weeks. Once their claim for export has been approved, insured persons may move to the country where they want to look for a job, notify the competent employment services of their arrival and comply with that country's control procedures.

If the person does not find employment within 3 months, he/she can return to Switzerland and continue to receive unemployment insurance benefits. The CD of the FDFA provides a special service for Swiss nationals abroad who intend to return to the home country. In particular, the $\mathrm{CD}$ helps preparing the job search in Switzerland, forwarding job applications to the respective cantonal employment offices.

\subsubsection{Health Care}

The Federal Law on Health Insurance holds that health insurance is solely mandatory for those living in Switzerland. However, agreements concluded with the EU and EFTA have brought about exceptions to this rule for the following categories of Swiss nationals abroad: cross-border workers and their family members; pensioners and their family members; Swiss nationals abroad drawing unemployment benefits in Switzerland and their family members, as well as family members of temporary residents in Switzerland. As a general principle, these individuals have the possibility to choose between health care in their country of residence or in Switzerland. Swiss pensioners abroad must continue to hold basic health insurance with a Swiss provider for themselves and their dependents; but this rule does not apply to pensioners living in Austria, Italy, Germany, France, and Spain, as one of the conditions that are part of the Agreement with the EU on the Free Movement of Persons signed on 21 June 1999. The rule also does not apply to those individuals who are receiving a pension from their country of residence, even if the pension received in the 
country of residence is lower than the Swiss pension. Finally, if the pensioner is domiciled in a country from which he/she does not receive a pension but receives a Swiss pension and a pension from another EU/EFTA state, he/she must stipulate insurance in the country in which he/she has held insurance for the longest period for retirement pension purposes.

For all other categories of Swiss nationals living in EU/EFTA Member States, the Agreement on the freedom of movement of persons concluded between Switzerland and these countries establishes coordination of the social insurance systems. Within the health insurance framework, the Agreement stipulates that the appropriate place for health care coverage is the country in which the person is working. For example, a Swiss citizen working and residing in Italy will be governed by the Italian health insurance regime.

When a Swiss national emigrates to a state outside of the EU/EFTA, it is no longer possible for her/him to remain in the compulsory basic health insurance scheme. Health insurance companies have the possibility to privately provide health insurance plans for abroad.

The OSA offers information services in these matters, such as answering legal questions, indicating companies that propose international health insurance, explaining the consequences of emigration on the social insurance scheme, and providing information on the specific regulations concerning health legislation.

Consulates can assist individuals finding a doctor or setting up a visit in the hospital. The policy of social security for Swiss citizens abroad also allows consulates to anticipate the money to cover to emergency health care, if needed.

\subsubsection{Pensions}

Independently of the country where they reside, all Swiss citizens are entitled to a Swiss old-age pension if they have paid their pension contribution for at least 1 year. They are also entitled to a Swiss invalidity pension if they have paid their contribution for at least 3 years. The old-age and survivors' insurance (OASI) and the disability insurance (DI) are compulsory only for individuals living in Switzerland. Swiss nationals abroad have the possibility, in principle, of joining the optional OASI/DI scheme. This optional insurance aims to avoid a situation where, in the event of an accident or at retirement age, they or their survivors, may not receive a pension at all or only receive one on the basis of the years of pension contribution paid under the compulsory pension insurance system and contributions paid as such. In fact, failure to pay one single year of contribution to the voluntary scheme leads, as a general rule, to a reduction of the pension. Those who wish to join the voluntary OASI insurance scheme should present their request to the Swiss Compensation Office (SCO) in Geneva. This request must be sent within 1 year of leaving the compulsory insurance scheme and the cost of the insurance depends on the employment condition - past and present - of the individual. 
Table 21.4 Annual subsidies of the Swiss Federal Council to the Swiss Schools Abroad (1980-2015)

\begin{tabular}{l|l|l|l}
\hline School & Students & Swiss Students & Funding in francs \\
\hline Bangkok & 264 & 43 & 602.952 \\
\hline Barcelona & 656 & 156 & 1.702 .447 \\
\hline Bergamo & 176 & 28 & 371.704 \\
\hline Bogota & 727 & 144 & 1.811 .615 \\
\hline Curitiba \& Sao Paulo & 1.369 & 179 & 2.108 .004 \\
\hline Catania & 92 & 24 & 260.833 \\
\hline Lima & 715 & 233 & 1.741 .247 \\
\hline Madrid & 560 & 82 & 1.157 .986 \\
\hline Milan & 515 & 151 & 1.542 .882 \\
\hline Mexico City, Cuernavaca, Querétaro & 1.424 & 141 & 2.338 .670 \\
\hline Rome & 504 & 145 & 1.632 .025 \\
\hline Santiago de Chile & 729 & 176 & 1.829 .954 \\
\hline Singapore & 277 & 153 & 1.119 .574 \\
\hline Total & 8.008 & 1.655 & 18.219 .893 \\
\hline
\end{tabular}

Source: Own elaboration based on information from the Federal Office of Culture. Note: The 18th Swiss School Abroad, the School of Beijing, is not in the list because it was recognised in December 2017

\subsubsection{Family-Related Benefits}

Family-related benefits are not accessible to Swiss nationals abroad (although Swiss family allowances can also be paid for children residing in the EU/EFTA). The Federal Council, however, provides some indirect support to families abroad through financial incentives for the education of pupils in Swiss schools and for short return trips to Switzerland for Swiss children who live abroad. These activities are coordinated by the Federal Office of Culture.

Swiss schools abroad are subsidised by the Swiss Confederation provided they meet the requirements of the Federal Act on the Provision of Swiss Education Abroad (Swiss Schools Act) of 21 March 2014..$^{22}$ Currently, the Swiss Confederation recognises 18 Swiss schools abroad, five of which are in South America, four in Italy, two in Spain, and two in Asia (Table 21.4).

The Federal Office of Culture is responsible for the promotion and recognition of Swiss schools abroad and it works together with the association educationsuisse, which represents the interests of the Swiss schools with the Swiss authorities. The association also provides information about the range of international schools supported by the Federal Council. Swiss families abroad who do not live in the vicinity of a Swiss school, but who wish to provide their children with Swiss training, can

\footnotetext{
${ }^{22}$ Loi fédérale sur la diffusion de la formation suisse à l"étranger, 21/3/2014. See also: Ordonnance sur la diffusion de la formation suisse à l'étranger, 28/11/2014; and the debates in the Federal Assembly: Message concernant la loi fédérale sur la transmission de la formation suisse à l'étranger, 7/6/2013.
} 
apply for support from the Confederation for the following three actions: (1) recruiting a Swiss teacher at a German, French, or international school abroad; (2) establishing courses on the history and geography of Switzerland and national languages; (3) purchasing of Swiss educational material. The promoter or applicant must in any case be an association of Swiss parents or a Swiss organization.

In addition to this service, the Federal Office of Culture also supports the Foundation for Young Swiss Abroad (FYSA, Stiftung für junge Auslandschweizer). This charity provides resources for Swiss children living abroad to spend some time in Switzerland. The charity was initially established on the initiative of a small group of volunteers who, in 1917, brought to Switzerland 280 Swiss children from war zones in Germany. Children spent a few weeks of holiday and were hosted by families. The cost of this initiative was met in full by the Federal Council. The following year, a private committee was formed under the name of "Swiss Aid", which set itself the objective of continuing and building upon the aid work started. In October 1979, a decision was made to change the name of the Foundation from "Swiss Aid" to the "Foundation for Young Swiss Abroad". Today, the Foundation relies on the administrative structures of the OSA, therefore relying indirectly on federal funding. It is composed of ten cantonal committees, which organise annual fundraising events. In total, the Federal Office of Culture spends about 20 million francs per year on Swiss schools abroad, which represents $15 \%$ of the total budget.

\subsubsection{Economic Hardship}

There is no policy concerning the guaranteed minimum resources for Swiss nationals abroad. However, consulates and embassies often provide financial support to Swiss nationals abroad who do not have sufficient economic resources through the Social security for Swiss citizens abroad overseen by the Consular Directorate (CD) at the FDFA in Bern. As previously noted, this policy allows for structured welfare funding. According to the government officials interviewed for this research, the majority of recipients of social assistance abroad have received funding from the $\mathrm{CD}$ for several years now.

\subsection{Conclusions}

Social policies for Swiss nationals abroad revolve around the institutionalisation of a large network that is: (i) overseen by the Federal Council, mainly the FDFA and, to a lesser extent, the Federal Office of Culture; (ii) coordinated by non-profit organisations funded to work together with the Federal Council, mainly the OSA and, in some specific domains, the Foundation for Young Swiss Abroad and educationsuisse; (iii) implemented by the consulates and the embassies; (iv) complemented by the activities of the 750 Swiss associations, charities, and clubs around the world. 
This constitutes a "guichet unique" for what is, in fact, a broad range of policies and actors.

This highly institutionalised system has developed quite recently. Until the late 1960s, the social protection of Swiss nationals abroad was uncoordinated and dependent upon cantonal authorities and benevolent societies. The Federal Council took over starting from 1966, with the introduction of what is now Article 40 of the Constitution, which encourages and supports relations between Switzerland and the Swiss abroad. In 1973, the Council approved the Federal Act on Social Assistance and Loans to Swiss Citizens Abroad. ${ }^{23}$ Since 2014, the social protection of Swiss abroad is mandated by the Federal Act on Swiss Citizens and Institutions Abroad. This legislation is a consequence of the recognition, by the Federal Council, that Swiss nationals abroad have a crucial role on two fronts. Internally, they shape politics through their right to vote and stand as candidates in federal elections and in some cantonal elections. Externally, they are considered informal ambassadors of the country, a particularly important role also because Switzerland is not part of the EU and must find alternative ways to make its voice heard. As part of this strategy, the Federal Council developed more encompassing social protection policies, while safeguarding pre-existent cantonal associations. Today, Swiss nations abroad can access a wide set of social entitlements.

Acknowledgments This chapter is part of the project "Migration and Transnational Social Protection in (Post)Crisis Europe (MiTSoPro)" that has received funding from the European Research Council (ERC) under the European Union's Horizon 2020 research and innovation programme (Grant agreement No. 680014). In addition to this chapter, readers can find a series of indicators comparing national social protection and diaspora policies across 40 countries on the following website: http://labos.ulg.ac.be/socialprotection/. Research for this chapter has been funded by the National Center of Competence in Research (NCCR) on the move funded by the Swiss National Science Foundation. The author wishes to thank the editors for their extraordinary work and the interviewees for their time and dedication.

\section{References}

Andrzejewski, M. (2002). Schweizer in Polen: Spuren der Geschichte eines Brückenschlages. Basel: Schwabe.

Arlettaz, G. (1979). Émigration et colonisation suisses en Amérique, 1815-1918. Bern: Archives fédérales suisses.

Arlettaz, G. (1986). Les "Suisses de l'étranger" et l'identité nationale. Etudes et sources, 12, 5-35.

Arrighi, J.-T. \& Piccoli, L. (2018). SWISSCIT: Index on citizenship law in Swiss cantons. https:// indicators.nccr-onthemove.ch/how-inclusive-are-citizenship-laws-in-the-26-swiss-cantons/ Accessed 18 March 2019.

Bovay, E. H. (1976). Le Canada et les Suisses (pp. 1604-1974). Fribourg: Editions universitaires.

Bühler, R., et al. (1985). Schweizer im Zarenreich: zur Geschichte der Auswanderung nach Russland. Zürich: H. Rohr.

${ }^{23}$ Loi fédérale sur l'assistance des Suisses de l'étranger, 21/3/1973. 
Camenisch, A., \& Müller, S. (2017). From (E) Migration to Mobile Lifestyles: Ethnographic and Conceptual Reflections about Mobilities and Migration. New Diversities, 19(3), 43-57.

Chinezu, C. (2002). Suisses en Roumanie. Fribourg: Foundation Sturdza \& Weidmann.

Dewulf, J. (2007). Brasilien mit Brüchen: Schweizer unter dem Kreuz des Südens. Zürich: Verl. Neue Zürcher Zeitung.

Geissbuhler, S. (1999). The Bernese emigration to the United States, 1870-1930: A quantitative analysis of economic factors. Migracijske teme, 15(3), 377-391.

Glatz, M. (1997). Schweizerische Einwanderer in Misiones: ein Beispiel ausländischer Siedlungskolonisation in Argentinien im 20. Jahrhundert. Frankfurt: P. Lang.

Leu, S. (2016). La construction de la Cinquième Suisse au coeur de l'internationalisation de l'économie. Politorbis, 62(2), 31-32.

Nicoulin, M. (1988). La genèse de Nova Friburgo : émigration et colonisation suisse au Brésil : 1817-1827. Fribourg: Ed. universitaires.

Perret, M. E. (1950). Les colonies tessinoises en Californie. Lausanne: F. Rouge.

Schneiter, F. (1983). Die schweizerische Einwanderung in Chile = La inmigración suiza en Chile. Bern: Stämpfli.

Wegmann, S. (1989). The Swiss in Australia. Grüsch: Verlag Rüegger.

Open Access This chapter is licensed under the terms of the Creative Commons Attribution 4.0 International License (http://creativecommons.org/licenses/by/4.0/), which permits use, sharing, adaptation, distribution and reproduction in any medium or format, as long as you give appropriate credit to the original author(s) and the source, provide a link to the Creative Commons license and indicate if changes were made.

The images or other third party material in this chapter are included in the chapter's Creative Commons license, unless indicated otherwise in a credit line to the material. If material is not included in the chapter's Creative Commons license and your intended use is not permitted by statutory regulation or exceeds the permitted use, you will need to obtain permission directly from the copyright holder. 